\title{
MENINGKATKAN KEMAMPUAN KOMUNIKASI DAN PENALARAN SERTA DISPOSISI MATEMATIK SISWA SMK DENGAN PENDEKATAN KONTEKSTUAL MELALUI GAME ADOBE FLASH CS 4.0
}

Oleh:

\author{
Martin Bernard \\ Pendidikan Matematika, STKIP Siliwangi Bandung \\ pamartin23rnard@gmail.com
}

\begin{abstract}
ABSTRAK
Penelitian ini bertujuan untuk menelaah pencapaian dan peningkatan kemampuan komunikasi dan penalaran matematik siswa yang pembelajaran dengan pendekatan kontekstual melalui game Adobe Flash CS 4.0 lebih baik daripada pembelajaran kontekstual dengan cara biasa, menalaah asosiasi kemampuan komunikasi dan penalaran matematika siswa, asosiasi skala disposisi dan kemampuan komunikasi dan asosiasi skala disposisi dan kemampuan penalaran. Serta bagaimana menelaah kemampuan komunikasi dan penalaran matematik siswa terhadap pendekatan pembelajaran. Metode penelitian yang dipakai adalah menggunakan kuasi eksperimen. Dimana metode ini terdiri dua kelas, bahwa kelas pertama diberi perlakuan yaitu kelas yang pembelajaran pendekatan kontekstual menggunakan game Adobe Flash CS 4.0 dan kelas yang kedua yaitu kelas yang pembelajaran pendekatan kontekstual dengan cara biasa. Populasi yang diambil di sekolah SMK Mahardika dan sampelnya adalah 40 siswa kelas X.1 sebagai kelas Kontrol dan 42 siswa kelas X.2 sebagai kelas Eksperimen. Instrumen yang digunakan berupa 10 butir soal diantaranya 5 soal kemampuan komunikasi dan 5 soal kemampuan penalaran berbentuk uraian yang telah diuji validitas, realibilitas, derajat pembeda dan indeks kesukaran. Untuk angket skala disposisi yang digunakan adalah angket skala Linkert yang berbentuk ordinal yang akan dikonversi ke bentuk interval melalui Method Seccessive Interval (MSI). Kesimpulan dari penelitian tersebut yaitu pencapaian dan peningkatan kemampuan komunikasi dan penalaran serta disposisi matematik siswa dengan pendekatan kontekstual melalui Game Adobe Flash CS 4.0 lebih baik dibandingkan dengan pembelajaran cara biasa, adanya asosiasi antara kemampuan komunikasi dan penalaran tetapi tidak ada asosiasi antara disposisi dengan kemampuan komunikasi dan penalaran.
\end{abstract}

Kata Kunci : Komunikasi, Penalaran, Skala Disposisi, Pendekatan Kontekstual, Adobe Flash CS 4

\begin{abstract}
This study aimed to examine the achievement and improvement of communication skills and mathematical reasoning students learning with contextual approach through the game Adobe Flash CS 4.0 is better than contextual learning in the normal way, examine the association of communication and mathematical reasoning abilities of students, associations scale disposition and communication skills and association scale disposition and reasoning
\end{abstract}


abilities. And how to examine the communication skills and mathematical reasoning students towards learning approaches. The research method is to use a quasi-experimental. Where this method consists of two classes, that first class was given a treatment that learning classes contextual approach using games Adobe Flash CS 4.0 and the second class is the class that learning contextual approach in the usual manner. Population taken in Mahardika SMK schools and the sample was 40 students of class X.1 as the Control class and 42 students X.2 class as a class experiment. Instruments used in the form of 10 items including 5 questions about the communication skills and reasoning abilities shaped 5 description has tested the validity, reliability, degree of differentiation and difficulty index. For dispositions scale questionnaire used was a questionnaire form ordinal scale Linkert be converted to form the interval through Seccessive Method Interval (MSI). The conclusion from these studies is the attainment and improvement of communication skills and mathematical reasoning and the disposition of the students with contextual approach through Game Adobe Flash CS 4.0 is better than the usual way of learning, the association between communication and reasoning capabilities, but there is no association between disposition with communication capabilities and reasoning.

Keywords: Communication, Reasoning, Scale Disposition, Contextual Approach, Adobe Flash CS 4

\section{PENDAHULUAN}

Mata pelajaran Matematika perlu diberikan kepada semua peserta didik mulai dari sekolah dasar untuk membekali peserta didik dengan kemampuan berpikir logis, analitis, sistematis, kritis, dan kreatif, serta kemampuan bekerjasama. Kompetensi tersebut diperlukan agar peserta didik dapat memiliki kemampuan memperoleh, mengelola, dan memanfaatkan informasi untuk bertahan hidup pada keadaan yang selalu berubah, tidak pasti, dan kompetitif.

Salah satu tujuan pembelajaran matematika adalah untuk melatih cara berpikir dan bernalar dalam menarik kesimpulan serta mampu mengungkapkan pendapatnya dengan rasa percaya diri dan kejujuran yang timbul dari seseorang untuk memecahkan masalah yang dihadapi. Berdasarkan kemampuan siswa bahwa tujuan pembelajaran dapat ditetapkan hendak dicapai dan dikembangkan serta diapresiasikan. Menurut National Council of Teacher of Mathematics (NCTM) tujuan umum siswa belajar matematika yaitu; (1) belajar akan nilai-nilai matematika, memahami evolusi, dan peranan dalam masyarakat serta sains, (2) percaya diri pada kemampuan yang dimiliki, percaya pada berfikir matematis yang dimiliki dan peka terhadap situasi dan masalah, (3) menjadi seorang problem solver, menjadi warga negara yang produktif dan berpengalaman dalam memecahkan berbahgai permasalahan, (4) belajar berkomunikasi secara matematis, belajar tentang simbol, lambang dan kaedah matematis, (5) belajar bernalar secara matematis yaitu membuat konjektur, bukti, dan membangun argumen secara matematis (Romberg dalam Hulu, 2009). 
Berdasarkan indikator ke lima menurut NCTM bahwa penalaran merupakan salah satu kemampuan siswa untuk proses pembelajaran matematika. Penalaran merupakan cara berpikir siswa yang logis secara pendekatan induktif yaitu pembelajaran memberikan bukti yang logis untuk mencapai kesimpulan dan pembelajaran deduktif yaitu konsep-konsep penyelesaian masalah yang berdasarkan penguasaan ilmu yang telah terbukti sehingga siswa dapat berpikir secara logis berdasarkan fakta yang ada untuk menarik kesimpulan. Dari penjelasan tersebut bahwa berpikir penalaran, siswa dapat memunculkan ide atau gagasannya menjadikan cara untuk memecahkan masalah.

Baroody (1993) mengatakan bahwa penalaran adalah alat yang penting untuk matematika dan kehidupan sehari-hari. Dapat diartikan bahwa siswa dalam mempelajari matematika memerlukan penalaran untuk mencetuskan ide sehingga siswa dapat memahami konsep matematika yang benar.

Kemampuan lain yang tak kalah penting dalam pembelajaran matematika adalah komunikasi. Kemampuan komunikasi harus dimiliki agar siswa dapat memahami permasalahan matematika yang diberikan dan mengutarakan idea-idea penyelesaian dari permasalahan tersebut bukan hanya idea untuk menarik kesimpulan pada kemampuan penalaran, serta memberikan argumen atas idea yang diutarakannya. Materi matematika disampaikan melalui suatu bahasa yang universal. "Salah satu ciri utama matematika adalah penggunaan simbol-simbol untuk menyatakan sesuatu, misalnya menyatakan suatu fakta, konsep operasi ataupun prinsip/ aturan." (Soetjadi, 2000:199). Kusumah (Hutapea, 2013) menyatakan bahwa melalui komunikasi, memungkinkan tereksploitasinya ide matematis melalui komunikasi, memungkinkan tereksploitasinya ide matematis melalui berbagai perspektif, mempertajam cara berfikir siswa, dapat mengukur perkembangan pemahaman, dapat mengorganisir pemikiran siswa, dapat mengkonstruksi pengetahuan matematis dan pengembangan masalah siswa, meningkatkan penalaran, dan membentuk komunikasi.

Upaya yang dilakukan untuk meningkatkan kemampuan siswa dalam penalaran dan komunikasi pembelajaran matematik. Pembelajaran siswa pada dasarnya siswa lebih menyukai permainan daripada mereka harus belajar secara monoton. Hal ini peran guru adalah memberikan cara proses pembelajaran matematik yang menyenangkan. Di sini perlu membuat rancangan dimana guru memiliki daya kreativitas yang memiliki tujuan yaitu meningkatkan kualitas anak dalam pembelajaran matematika. Sehingga dapat diharapkan interaksi antara siswa dan guru adalah suatu hal yang penting untuk membangun pengetahuan matematika, mengembangakan kemampuan komunikasi dan penalaran, memperoleh keterampilan, bersosialisasi, dan menigkatkan sikap siswa terhadap pembelajaran matematika. Dengan hal ini dapat dirancangkan siswa menjadi lebih aktif dalam belajar matematik. Sesuai dengan dunia modern salah satu yang ramai digunakan adalah model pembelajaran berbasis teknologi atau lebih dikenal pembelajaran multimedia. Hal ini mengandung tujuan 
bahwa di dalam pembelajaran guru dituntut mampu menerapkan metode yang mengikuti perkembangan ilmu dan teknologi.

Metode pembelajaran multimedia melalui media presentasi interaktif sederhana diharapkan dapat memberikan pengalaman baru dan menyenangkan baik bagi guru maupun siswa. Selain pembelajaran yang lebih bervariasi, siswa dapat termotivasi untuk belajar dan menyenangi apa yang dipelajarinya.

Saat ini kendala guru mengajarkan kepada siswa adalah merancang produk memanfaatkan teknologi agar pada waktu mengajar kepada siswa dapat tercapai, yaitu guru harus mampu dan mudah menggunakannya dan praktis, salah satu multimedia yang digunakan adalah Adobe Flash CS 4.0, karena dengan menggunakan software tersebut kita dapat membuat game matematika sehingga siswa lebih semangat untuk belajar.

Kenapa game edukatif sangat penting, karena orang bisa merasakan terhibur namun di sisi lain, masalah ketagihan pada game tidak bisa dihindarkan seseorang bisa bertahan berjam-jam bermain game sampai lupa makan dan minum. Mereka lebih suka bermain dan sampai mereka mengerti cara proses permainan tersebut. Namun jika kita menggantikan proses permainan tersebut dengan game matematika dan mengerti konsep-konsep matematika di dalam permainan tersebut bisa jadi mereka mampu menguasai matematika.

Dalam penelitian Maria Virvou dkk (Hidayatullah, 2011) tentang efektivitas game dalam membantu proses pembelajaran. Mereka menyatakan bahwa game edukatif virtual reality yang mereka buat (VR-ENGAGE) dapat sangat memotivasi sambil meningkatkan efek edukatif pada siswa. Yang menarik adalah beliau bercerita dalam paper-nya bahwa di sekolah yang menjadi tempat penelitiannya, dulu ada siswa yang membuat suasana kelas kurang kondusif. Dia sering mengganggu temannya yang sedang belajar. Namun sejak diimplementasikannya VR-ENGAGE ini, siswa tersebut tidak pernah mengganggu temannya.

Permainan dilakukan dengan bantuan alat elektronik yaitu TIK yang berbasis game Adobe Flash CS 4.0 sebagai alat bantu untuk membuat sebuah permainan dalam pembelajaran matematik yang lebih menyenangkan dan juga diharapkan siswa dapat memberikan ide dan dapat mengapresisasikan metematika serta mampu memiliki sikap keingintahuan yang besar mengenai teknologi tepat guna. Selain hanya memberikan jawaban atau gagasan permasalahan yang diajukan. Dan karena ide tersebut dikaitkan dengan simbol-simbol matematika dengan gambar animasi maka pendekatan pembelajaran yang cocok yaitu menggunakan pendekatan kontekstual.

Model pembelajaran melalui Game Adobe Flash CS 4.0 juga dapat bertujuan memberikan semangat kepada siswa untuk percaya diri menggunakan konsep matematika, gigih dan ulet mengerjakan matematika, mengemukakan pendapatnya dan berpikir secara logis serta mampu membuat suatu kesimpulan. 


\section{KAJIAN PUSTAKA}

\section{Kemampuan Komunikasi}

Komunikasi adalah suatu proses penyampaian informasi atau pesan kepada orang lain dan sebaliknya sehingga apa yang diungkapkan tersebut dapat dipahami dan dimengerti dengan baik. Menurut TIM (Elida, 2012:180) menyatakan bahwa komunikasi adalah pengiriman dan penerimaan pesan antara dua orang atau lebih sehingga pesan yang dimaksud. Jadi dalam pembelajaran matematika, ketika sebuah konsep informasi matematika diberikan oleh seorang guru kepada siswa ataupun siswa dilibatkan secara aktif dalam mengerjakan matematika, memikirkan ide-ide mereka, menulis, atau berbicara dengan dan mendengarkan siswa lain, dalam berbagi ide, maka saat itu sedang terjadi transformasi informasi matematika dari komunikator kepada komunikan, atau sedang terjadi komunikasi matematika. Sedangkan Abdulhak (Elida, 2012:180) berpendapat bahwa komunikasi dimaknai sebagai proses penyampaian pesan dan pengiriman pesan melalui tujuan tertentu. Dalam hal ini diperjelas bahwa setiap keterangan informasi harus benar-benar tersampaikan dengan jelas apakah syarat-syarat yang harus dipenuhi dan maksud dan tujuan yang akan disampaikan sehingga dapat dikomunikasikan dengan baik.

Sumarmo (2003) bahwa indikator-indikator komunikasi matematis meliputi kemampuan siswa:

a. Menghubungkan benda nyata, gambar. Dan diagram ke dalam idea matematika;

b. Menjelaskan idea, situasi dan relasi matematik secara lisan atau tulisaan dengan benda nyata, gambar, grafik dan aljabar;

c. Menyatakan peristiwa sehari-sehari dalam bahasa simbol matematika;

d. Mendengarkan, berdiskusi, dan menulis tentang matematika;

e. Membaca dengan pemahaman atau presentasi matematika tertulis;

f. Membuat konjektur, menyusun argument, merumuskan definisi dan generalisasi;

g. Menjelaskan dan membuat pertanyan tentang matematika yang telah dipelajari.

Dari indikator-indikator tersebut menjadi ukuran guru untuk mengembangkan siswa untuk mampu mengkomunikasikan hasil dari keterkaitan antara masalah matematika dengan gambar, grafik, dan simbol-simbol matematika menjadi alat penyelesaian masalah.

\section{Kemampuan Penalaran}

Pengertian kemampuan penalaran siswa biasanya dihubungkan dengan cara proses siswa berpikir dengan cara kerja otak korteks berdasarkan bukti-bukti yang ada, hal ini sesuai dengan definisi penalaran, Keraf (1982: 5) menjelaskan penalaran (jalan pikiran atau reasoning) sebagai: "Proses berpikir yang berusaha menghubunghubungkan fakta-fakta atau evidensi-evidensi yang diketahui menuju kepada suatu 
kesimpulan". Penalaran adalah salah satu kemampuan proses berpikir matematika yang yang mengkaitkan untuk menyelesaikan masalah matematika berdasarkan fakta-fakta atau bukti yang kongkrit sehingga siswa mampu menarik kesimpulan bagaimana cara siswa dapat menggunakan konsep atau metode yang diperolehnya.

Sumarmo (2012: 17) berdasarkan penarikan kesimpulan, bahwa kemampuan penalaran dapat di klarifikasikan dengan dua jenis yaitu penalaran induktif dan penalaran deduktif. Biasanya banyak pandangan orang pada umumnya berpendapat bahwa penalaran induktif adalah proses melakukan pengamatan dari khusus ke umum dengan melakukan beberapa percobaan sampai mendapatkan kesimpulan berdasarkan pengamatan sampai mendapat kesimpulan dari hasil pengamatan, dan penalaran deduktif adalah melakukan pernyataan definisi atau pengertian yang sudah kesepekatan untuk menyelesaikan suatu masalah tertentu atau bisa dikatakan dari umum untuk berlaku kepada pernyatan khusus.

Sumarmo (2012:17) bahwa penalaran induktif tidak hanya sekedar dari dari khusus ke umum tetapi penalaran induktif memiliki beberapa kegiatan yaitu, a) Penalaran transduktif yaitu proses penarikan kesimpulan, b) penalaran analogi yaitu penarikan kesimpulan berdasarkan keserupaan proses atau data, c) penalaran generalisasi yaitu penarikan kesimpulan secara umum berdasarkan data yang terbatas; d) Memperkirakan jawaban, solusi atau kecenderungan: interpolasi dan ekstrapolasi; e) memberikan penjelasan terhadap model, fakta, sifat, hubungan atau pola yang ada; f) Menggunakan pola hubungan untuk menganalisis situasi, dan menyusun konjektur. Jadi untuk pernyataan khusus ke umum dalam penalaran induktif merupakan bagian dari pengertian dari kegiatan penarik kesimpulan bukan definisi secara umum, dapat saja bahwa hal itu adalah kategori generalisasi. Karena itu untuk melakukan kegiatan penalaran siswa dapat dilakukan berdasarkan keenam item tersebut, jadi kemampuan berpikir penalaran siswa bukan pernyataan tertutup yang menyatakan kepastian menjawab tetapi pernyataan terbuka artinya siswa dapat menyatakan dugaan dari beberapa kemungkinan siswa akan terdorong untuk mencoba dari berbagai jawaban sampai akhirnya mendapatkan kesimpulan. Demikian juga menurut Sumarmo (2012:21) Penalaran deduktif adalah penarik kesimpulan berdasarkan aturan yang disepakati. Dan beberapa kegiatan yang tergolong pada penalaran deduktif diantaranya adalah, a) Melaksanakan perhitungan berdasarkan aturan atau rumus tertentu secara konsep, kemampuan ini tergolong berpikir matematik tingkat rendah, karena hanya melakukan perhitungan saja; b) Penalaran logis matematik berdasarkan aturan inferensi, memeriksa validitas, argumen, membuktikan dan menyusun argumen yang valid; c) Menyusun pembuktian langsung, pembuktian tak langsung dan pembuktian dengan induksi matematika. Jadi penalaran deduktif, tidak perlu melakukan percobaan atau dugaan benar dan salah, tetapi cukup melihat dari aturan-aturan yang sudah disepakati, hanya yang dipelu diperhatikan untuk menyelesaikan masalah harus menggunakan kalimatkalimat matematika logika sehingga siswa mendapatkan jawabannya. Dari pengertian penalaran induktif dan deduktif maka penalaran adalah proses berpikir 
untuk menyelesaikan masalah dari beberapa bukti apakah berdasarkan percobaan atau pengalaman siswa tentang konsep matematika yang mereka kuasai, Ini sejalan menurut Suria Sumantri (Jupri, 2004:16) Penalaran adalah suatu proses berpikir dalam menarik kesimpulan yang berupa pengetahuan, kegiatan berpikir yang mempunyai karakteristik tertentu dalam menemukan kebenaran, dan berpikir penalaran memiliki ciri-ciri tertentu.

Dari beberapa item-item untuk penyelesaian masalah-masalah matematik dengan kemampuan penalaran induktif, siswa harus dibiasakan yang tujuannya agar menambahkan pengalaman siswa untuk mengetahui konsep dari beberapa dugaan sehingga siswa mampu mencirikan kasus-kasus dilihat dari pola (analogi) dan membuat dugaan tentang hubungan yang ada diantara kasus-kasus itu, serta selanjutnya menyatakan hubungan yang berlaku umum (generalisasi). Selain itu siswa menyadari kesalahan dalam proses pengerjaan matematika, memperkirakan jawaban berdasarkarkan fakta-fakta dari kegiatan pengamatan siswa sehingga siswa mampu membuat kesimpulan yang tepat. Dan untuk kemampuan penalaran deduktif, siswa sudah memahami dan menguasai konsep-konsep yang sudah dipelajari di kelas sehingga mampu menghitung dari soal-soal dari kategori yang mudah sampai yang tersulit, juga berpikir logis dengan proposional, probabilitik, korelasional dan kobinatorik, disini siswa dibiasakan mengenal simbol-simbol matematika dan bentuk pernyataan-pernyataan martematika berupa modus ponen, modus tolens, modus silogime sehingga memperoleh hasil dari premis-premis berdasarkan fakta umum yang sudah disepakati.

\section{Disposisi Matematika}

Setelah diberi perlakuan terhadap pendekatan pembelajaran diharapkan siswa adanya rasa percaya diri, kejujuran, bertanggung jawab dan upaya siswa untuk bekerja keras dalam menyelesaikan masalah perlu diukur dari disposisi matematik siswa. Berdasarkan definisi menurut NCTM(1989) menyatakan disposisi matematis adalah keterkaitan dan apresiasi terhadap matematika yaitu suatu kecenderungan untuk berpikir dan bertindak dengan cara yang positif.

Sejalan dengan hal di atas, Wardani (2008: 15) mendefinisikan disposisi matematis adalah ketertarikan dan apresiasi terhadap matematika yaitu kecendrungan untuk berpikir dan bertindak dengan positif, termasuk kepercayaan diri, keingintahuan, ketekunan, antusias dalam belajar, gigih menghadapi permasalahan, fleksibel, mau berbagi dengan orang lain, reflektif dalam kegiatan matematik (doing math). Sedangkan menurut Mulyana (2009:19) disposisi terhadap matematika adalah perubahan kecendrungan siswa dalam memandang dan bersikap terhadap matematika, serta bertindak ketika belajar matematika. Misalnya, ketika siswa dapat menyelesaikan permasalahan non rutin, sikap dan keyakinannya sebagai seorang pelajar menjadi lebih positif. Makin banyak konsep matematika dipahami, makin yakinlah bahwa matematika itu dapat dikuasainya. Tujuannya supaya 
kelemahan yang dialami siswa dapat tersolusikan langkah-langkah atau cara untuk mendorong upaya siswa lebih bertanggung jawab, gigih, rajin dan ulet untuk masalah matematika yang dihadapi.

Menurut Wardani (2008: 232), aspek-aspek yang diukur pada disposisi matematis adalah (1) kepercayaan diri dengan indikator percaya diri terhadap kemampuan/keyakinan; (2) keingintahuan terdiri dari empat indikator yaitu: sering mengajukan pertanyaan, melakukan penyelidikan, antusias/semangat dalam belajar, banyak membaca/mencari sumber lain; (3) ketekunan dengan indikator gigih /tekun/ perhatian/ kesungguhan; (4) flesibilitas, yang terdiri dari tiga indikator yaitu: kerjasama/berbagi pengetahuan, menghargai pendapat yang berbeda, berusaha mencari solusi/strategi lain; (5) reflektif, terdiri dari dua indikator yaitu bertindak dan berhubungan dengan matematika, menyukai/rasa senang terhadap matematika.

Untuk mengungkapkan disposisi matematis siswa, dapat dilakukan dengan membuat skala disposisi dan pengamatan. Skala disposisi memuat pernyataan-pernyataan masing-masing komponen disposisi. Misalnya "untuk pemahaman lebih mendalam, saya mencoba menyelesaikan soal matematika dengan cara lain". Melalui pengamatan, disposisi siswa dapat diketahui ada tidaknya perubahan pada saat siswa memperoleh atau mengerjakan tugas-tugas. Misalnya pada saat proses pembelajaran sedang berlangsung dapat dilihat apakah siswa dalam menyelesaikan soal matematika yang sulit siswa terus berusaha sehingga memperoleh jawaban yang benar.

\section{Pendekatan Kontekstual}

Berdasarkan definisi menurut NCTM (1989) menyatakan disposisi matematis adalah keterkaitan dan apresiasi terhadap matematika yaitu suatu kecenderungan untuk berpikir dan bertindak dengan cara yang positif.

Disposisi siswa terhadap matematika terwujud melalui sikap dan tindakan dalam memilih pendekatan menyelesaikan tugas. Apakah dilakukan dengan percaya diri, keingintahuan mencari alternatif, tekun, dan tertantang serta kecenderuangan siswa merefleksi cara berpikir yang dilakukannya. Refleksi adalah cara berpikir tentang apa yang baru dipelajari atau berpikir ke belakang tentang apa-apa yang sudah dilakukan di masa lalu. Refleksi merupakan respon terhadap kejadian, aktivitas, atau pengetahuan yang baru diterima (Irianto, 2007: 113 ). Refleksi siswa akan terlihat pada saat siswa berdiskusi, pernyataan langsung tentang materi pelajaran yang diperolehnya pada hari ini, catatan, dan hasil kerjanya.

Pembelajaran berbasis kontekstual menurut Sanjaya (Sugiyanto, 2009: 17) melibatkan tujuh komponen utama pembelajaran, yakni kontruktivisme, bertanya, menemukan, masyarakat belajar, pemodelan, refleksi dan penilaian sebenarnya. Model pembelajaran kontekstual memiliki tujuh komponen yaitu: 
a. Kontruktivisme, yaitu pengetahuan siswa dibangun oleh dirinya sendiri atas dasar pengalaman, pemahaman konsep, persepsi dan perasaan siswa, bukan dibangun atau diberikan oleh orang lain. Jadi, guru hanya berperan dalam menyediakan kondisi atau memberikan suatu permasalahan.

b. Inquiry (menemukan), dalam hal ini sangat diharapkan bahwa apa yang dimiliki siswa baik pengetahuan dan ketrampilan diperoleh dari hasil menemukan sendiri bukan hasil mengingat dari apa yang disampaikan guru. Inkuiri diperoleh melalui tahap observasi (mengamati), bertanya (menemukan dan merumuskan masalah), mengajukan dugaan (hipotesis), mengumpulkan data, menganalisa dan membuat kesimpulan.

c. Bertanya, dalam pembelajaran kontekstual, bertanya dapat digunakan oleh guru untuk mendorong, membimbing dan menilai kemampuan siswa. Sehingga siswa pun akan dapat menemukan berbagai informasi yang belum diketahuinya.

d. Masyarakat Belajar, hal ini mengisyaratkan bahwa belajar itu dapat diperoleh melalui kerja sama dengan orang lain. Masyarakat belajar ini dapat kita latih dengan kerja kelompok, diskusi kelompok, dan belajar bersama.

e. Pemodelan, agar dalam menerima sesuatu siswa tidak merasa samar atau kabur dan bingung maka perlu adanya model atau contoh yang bisa ditiru. Model tak hanya berupa benda tapi bisa berupa cara, metode kerja atau hal lain yang bisa ditiru oleh siswa.

f. Refleksi yaitu cara berpikir tentang apa yang telah dipelajari sebelumnya, atau apa- apa yang sudah dilakukan dimasa lalu dijadikan acuan berpikir. Refleksi ini akan berguna agar pengetahuan bisa terpatri dibenak siswa dan bisa menemukan langkah- langkah selanjutnya.

g. Penilaian yang sebenarnya ( Authentic Assessement) yaitu penilaian yang sebenarnya terhadap pemahaman konsep siswa. Penilaian yang sebenarnya tidak hanya melihat hasil akhir, tetapi kemajuan belajar siswa dinilai dari proses, sehingga dalam penilaian sebenarnya tidak bisa dilakukan hanya dengan satu cara tetapi menggunakan berbagai ragam cara penilaian.

\section{Pembelajaran Matematika Game Adobe Flash CS 4.0}

Dalam pembelajaran, Macromedia Flash merupakan gabungan konsep pembelajaran dengan teknologi audio-visual yang mampu menghasilkan fitur-fitur baru yang dapat dimanfaatkan dalam pendidikan. Pembelajaran berbasis multimedia dapat menyajikan materi pelajaran yang lebih menarik, tidak monoton, dan memudahkan penyampaian. Siswa dapat mempelajari materi pelajaran tertentu secara mandiri dengan komputer yang dilengkapi program multimedia.

Hidayatullah (2011:18) Langkah-langkah Pembelajaran Matematik Game Macromedia Flash adalah

a. Penyampaian tujuan dan memotivasi siswa.

Dalam langkah ini dilakukan penyampaian tujuan pembelajaran dengan menggunakan flash game dan memberikan motivasi kepada siswa. 
b. Kajian materi

Dalam langkah ini, guru mengajarkan materi yang disajikan dalam flash game.

c. Membagi media

Pada langkah ini, guru mulai mengenalkan media flash game sebagai alat pembelajaran dan mengajarkan cara-cara penggunaan media flash game.

d. Membimbing

Dalam langkah ini, guru membantu setiap siswa secara individual.

e. Evaluasi

Langkah evaluasi bertujuan untuk mengetahui hasil belajar siswa dari penggunaan media flash game.

f. Penghargaan

Pada langkah ini, guru memberikan penghargaan yang bertujuan untuk memotivasi siswa dalam pembelajaran.

\section{Penelitian yang Relevan}

Kristianto (2007) melakukan penelitian tentang penggunaan media pembelajaran animasi atau game simulasi komputer terhadap pemahaman konsep gerak ditinjau dari penalaran abstrak, studi kasus pokok bahasan gerak lurus, parabola, melingkar, dan bolak-balik. Tujuannya memberikan alternatif pembelajaran yang menarik untuk peningkatkan proses berpikir penalaran dan komunikasi siswa.

Hasil penelitian menurut Latifurrohman (2013) bahwa pengembangan ini adalah Produk media pembelajaran yang valid dengan kriteria baik. Kedua sampel berdistribusi normal dan homogen sehingga dilanjutkan uji-t dua sampel, dari uji-t diperoleh $t_{\text {hitung }}$ 3,19 dan $t_{\text {tabel }}$ 2,02 artinya thitung $>$ ttabel dengan kata lain ada perbedaan hasil belajar siswa yang menggunakan Media pembelajaran menggunakan Adobe Flash CS 4.0 dengan hasil belajar siswa yang menggunakan metode Konvensional.

Dari beberapa penelitian dapat disimpulkan bahwa (i) Adobe Flash CS 4.0 sangat membantu siswa untuk meningkatkan kemampuan komunikasi dan penalaran dalam bentuk konkrit dan abstrak. (ii) Adobe Flash CS 4.0 merupakan program komputer animasi yang lebih efektif saat mengajarkan kepada siswa. (iii) Adobe Flash CS 4.0, membantu guru untuk menuangkan gagasan yang inovatif sehingga tujuan belajar dan mengajar dapat tercapai. Oleh sebab itu, Adobe Flash CS 4.0 dapat dimanfaatkan dalam penelitian dalam mencapai tujuan yang diharapkan.

\section{ANALISIS DATA DAN PEMBAHASAN}

\section{Analisis Data}

Berdasarkan pengolahan data pretest, postest dan gain tidak ternormalisasi kemampuan Komunikasi dan Penalaran, diperoleh skor rata-rata $(\bar{x})$ berikut 
presentasi dari skor ideal (\%), deviasi standar (s). Data lengkap dapat disajikan pada Tabel 1

Tabel 1

Deskripsi Hasil Tes Kemampuan Komunikasi dan Penalaran Serta Skala Disposisi

\begin{tabular}{|c|c|c|c|c|c|c|c|}
\hline \multirow[t]{2}{*}{ Kemampuan } & & \multicolumn{3}{|c|}{$\begin{array}{c}\text { Pembelajaran dengan } \\
\text { Multimedia }\end{array}$} & \multicolumn{3}{|c|}{ Pembelajaran Konvensional } \\
\hline & & Pretest & Postest & Gain & Pretest & Postest & Gain \\
\hline \multirow{3}{*}{ Komunikasi } & & 4,53 & 13,32 & & 4,97 & 11,72 & \\
\hline & $\bar{x}$ & $22,65 \%$ & $66,67 \%$ & 0,57 & $24,85 \%$ & $58,60 \%$ & 0,45 \\
\hline & $\mathrm{s}$ & 1,58 & 3,73 & 0,24 & 1,42 & 4,06 & 0,26 \\
\hline \multirow{3}{*}{ Penalaran } & $\bar{x}$ & 4,55 & 14,76 & & 4,90 & 12,17 & \\
\hline & & $22,75 \%$ & $73,80 \%$ & 0,66 & $24,50 \%$ & $60,85 \%$ & 0,49 \\
\hline & $\mathrm{s}$ & 1,36 & 2,70 & 0,17 & 1,48 & 3,71 & 0,22 \\
\hline \multirow{2}{*}{\multicolumn{2}{|c|}{ Skala Disposisi }} & \multicolumn{3}{|c|}{ Eksperimen } & \multicolumn{3}{|c|}{ Kontrol } \\
\hline & & Ordin & & erval & Ordin & & Interval \\
\hline \multirow[t]{2}{*}{ Disposisi } & $\bar{x}$ & 108,4 & & 4,42 & 99,52 & & 123,37 \\
\hline & $\mathrm{s}$ & 8,11 & & 0,38 & 16,43 & & 22,79 \\
\hline
\end{tabular}

Keterangan : Skor Maksimum Ideal (SMI) tes kemampuan Komunikasi dan Penalaran $=20$

Berdasarkan Tabel 1, diduga saat pretest bahwa untuk Kemampuan Komunikasi Kelas Kontrol lebih baik dibandingkan dengan Kemampuan Komunikasi Kelas eksperimen jika dilihat dari nilai rata-rata dari dua kemampuan juga dilihat juga bahwa simpangan baku Kemampuan Komunikasi yang pembelajaran konvensional lebih kecil dibandingkan kelas Eksperimen, dapat dikatakan bahwa nilai tes siswa yang pembelajaran secara konvensional lebih seragam dibandingkan dengan nilai tes siswa yang pembelajarannya yang menggunakan Multimedia atau nilai tes siswa yang pembelajarannya yang menggunakan Multimedia lebih bervariasi dibandingkan dengan nilai tes pembelajarannya secara konvensional, tetapi rata-rata dan standar deviasi antara kedua kelas memiliki perbedaan yang sangat kecil, demikian juga pada kemampuan Penalaran pretest bahwa rata-rata kelas Kontrol lebih tinggi dibandingkan kelas Eksperimen dan menurut standar deviasi bahwa kelas Kontrol lebih seragam dibandingkan dengan kelas Eksperimen artinya nilai setiap siswa kelas Kontrol lebih mendekati dengan nilai rata-rata siswa daripada nilai setiap siswa kelas Eksperimen. Tetapi selisih rata-rata antara kedua kelas sangat kecil.

Demikian juga pada saat postest, ternyata rata-rata kemampuan Komunikasi dan kemampuan Penalaran untuk kelas Ekperimen lebih tinggi dibandingkan dengan kelas Kontrol dan juga pada sesuai dengan standar deviasi bahwa nilai siswa kelas Eksperimen lebih seragam dengan nilai siswa kelas Kontrol. 
Dan tampak pada nilai Gain bahwa Kelas Eksperimen dan kelas Kontrol tampak ada peningkatan tetapi tetapi rata-rata Gain kelas Eksperimen lebih tinggi daripada rata Gain Kelas Kontrol, dan selisih antara kedua rata-rata perbedaannya cukup tinggi juga.

Dari kedua kemampuan bahwa pada saat pretest dan postest rata-rata kelas Kontrol dan Eksperimen tampaknya rata-rata Kemampuan Penalaran lebih tinggi dibandingkan dengan Kemampuan Komunikasi artinya soal Kemampuan Komunikasi lebih sukar dibandingkan soal Kemampuan Penalaran.

Dan untuk skala Disposisi bahwa Kelas Eksperimen lebih tinggi rata-rata nilai dibandingkan dengan kelas Kontrol artinya bahwa kelas Eksperimen merespon positif dibandingkan kelas Kontrol.

Tabel 2

Crosstab Asosiasi antara Kemampuan Komunikasi dan Penalaran

\begin{tabular}{|c|c|c|c|c|c|c|}
\hline & & & \multicolumn{3}{|c|}{ Komunikasi } & \multirow[b]{2}{*}{ Total } \\
\hline & & & Tinggi & Sedang & Rendah & \\
\hline \multirow[t]{15}{*}{ Penalaran } & Tinggi & Count & 5 & 4 & 1 & 10 \\
\hline & & Expected Count & 1,7 & 6,3 & 2,0 & 10,0 \\
\hline & & $\%$ within Penalaran & $50,0 \%$ & $40,0 \%$ & $10,0 \%$ & $100,0 \%$ \\
\hline & & $\%$ within Komunikasi & $35,7 \%$ & $7,7 \%$ & $6,3 \%$ & $12,2 \%$ \\
\hline & & $\%$ of Total & $6,1 \%$ & $4,9 \%$ & $1,2 \%$ & $12,2 \%$ \\
\hline & Sedang & Count & 9 & 38 & 11 & 58 \\
\hline & & Expected Count & 9,9 & 36,8 & 11,3 & 58,0 \\
\hline & & $\%$ within Penalaran & $15,5 \%$ & $65,5 \%$ & $19,0 \%$ & $100,0 \%$ \\
\hline & & $\%$ within Komunikasi & $64,3 \%$ & $73,1 \%$ & $68,8 \%$ & $70,7 \%$ \\
\hline & & $\%$ of Total & $11,0 \%$ & $46,3 \%$ & $13,4 \%$ & $70,7 \%$ \\
\hline & Rendah & Count & 0 & 10 & 4 & 14 \\
\hline & & Expected Count & 2,4 & 8,9 & 2,7 & 14,0 \\
\hline & & $\%$ within Penalaran & $0,0 \%$ & $71,4 \%$ & $28,6 \%$ & $100,0 \%$ \\
\hline & & $\%$ within Komunikasi & $0,0 \%$ & $19,2 \%$ & $25,0 \%$ & $17,1 \%$ \\
\hline & & $\%$ of Total & $0,0 \%$ & $12,2 \%$ & $4,9 \%$ & $17,1 \%$ \\
\hline \multirow[t]{5}{*}{ Total } & & Count & 14 & 52 & 16 & 82 \\
\hline & & Expected Count & 14,0 & 52,0 & 16,0 & 82,0 \\
\hline & & $\%$ within Penalaran & $17,1 \%$ & $63,4 \%$ & $19,5 \%$ & $100,0 \%$ \\
\hline & & $\%$ within Komunikasi & $100,0 \%$ & $100,0 \%$ & $100,0 \%$ & $100,0 \%$ \\
\hline & & $\%$ of Total & $17,1 \%$ & $63,4 \%$ & $19,5 \%$ & $100,0 \%$ \\
\hline
\end{tabular}


Berdasarkan Tabel 2 di atas bahwa Siswa yang memiliki Rendah pada Kemampuan Komunikasi dan Rendah pada Kemampuan Penalaran ada 16 orang. Siswa yang memiliki Rendah pada Kemampuan Komunikasi dan Sedang pada Kemampuan Penalaran ada 11 orang. Siswa yang memiliki Rendah pada Kemampuan Komunikasi dan Tinggi pada Kemampuan Penalaran ada 1 orang. Siswa yang memiliki Sedang pada Kemampuan Komunikasi dan Rendah pada Kemampuan Penalaran ada 10 orang. Siswa yang memiliki Sedang pada Kemampuan Komunikasi dan Sedang pada Kemampuan Penalaran ada 38 orang. Siswa yang memiliki Sedang pada Kemampuan Komunikasi dan Tinggi pada Kemampuan Penalaran ada 4 orang. Siswa yang memiliki Tinggi pada Kemampuan Komunikasi dan Rendah pada Kemampuan Penalaran ada 0 orang. Siswa yang memiliki Tinggi pada Kemampuan Komunikasi dan Sedang pada Kemampuan Penalaran ada 9 orang. Siswa yang memiliki Tinggi pada Kemampuan Komunikasi dan Tinggi pada Kemampuan Penalaran ada 5 orang.

Dari keterkaitan jumlah siswa yang kemampuan Komunikasi Tinggi dan Kemampuan Penalaran Rendah lebih besar dibandingkan jumlah siswa yang Kemampuan Penalaran Tinggi dan Komunikasi Rendah ini berarti soal Kemampuan Komunikasi lebih sulit dibandingkan dengan soal Kemampuan Penalaran.

Ada 5 siswa yang menguasai soal Kemampuan Penalaran dan Kemampuan Komunikasi dan masih ada 4 siswa yang belum menguasai soal kemampuan Penalaran dan Kemampuan Komunikasi, dan ada 38 orang menguasai sedang terhadap soal kemampuan Penalaran dan Kemampuan Komunikasi.

Tabel 3

Uji Hitung Chi Kuadrat

Asosiasi untuk Kemampuan Komunikasi dan Penalaran

\begin{tabular}{lcrr}
\hline & Value & df & \multicolumn{2}{c}{$\begin{array}{c}\text { Asymp. Sig. (2- } \\
\text { sided) }\end{array}$} \\
\hline Pearson Chi-Square & $10,931^{\text {a }}$ & 4 &, 027 \\
Likelihood Ratio & 11,287 & 4 &, 024 \\
Linear-by-Linear Association & 7,095 & 1 &, 008 \\
N of Valid Cases & 82 & & \\
\hline
\end{tabular}

a. 4 cells $(44,4 \%)$ have expected count less than 5 . The minimum expected count is 1,71 .

Karena P-Value $=0,027$ maka $\mathrm{P}-$ Value $<0,05$ artinya $H_{0}$ ditolak dan $H_{1}$ diterima dan disimpulkan bahwa terdapat Asosiasi antara Kemampuan Komunikasi dan Kemampuan Penalaran. Dan untuk melihat besar ukuran dari koefisien kontingensi.

Tabel 4 
Koefisien Kontingensi

Asosiasi untuk Kemampuan Komunikasi dan Penalaran

\begin{tabular}{llrr}
\hline & & Value & Approx. Sig. \\
\hline Nominal by Nominal & Phi &, 365 &, 027 \\
& Cramer's V &, 258 &, 027 \\
& Contingency Coefficient &, 343 &, 027 \\
N of Valid Cases & & 82 & \\
\hline
\end{tabular}

Untuk melihat ukuran koefisien kontingensi asosiasi berdasarkan tabel 4 di dapatkan bahwa koefisien kontingensi 0,343 dan untuk nilai kontingensi maksimum adalah 0,816 maka diperoleh asosiasi antara Kemampuan komunikasi dengan Kemampuan Penalaran Siswa cukup.

Tabel 5

Crosstab Skala Disposisi dan Kemampuan Komunikasi

\begin{tabular}{|c|c|c|c|c|c|c|}
\hline & & & & omunikasi & & \\
\hline & & & Tinggi & Sedang & Rendah & Total \\
\hline Disposisi & Tinggi & Count & 4 & 5 & 2 & 11 \\
\hline & & Expected Count & 1,9 & 7,0 & 2,1 & 11,0 \\
\hline & & $\%$ within Disposisi & $36,4 \%$ & $45,5 \%$ & $18,2 \%$ & $100,0 \%$ \\
\hline & & $\%$ within Komunikasi & $28,6 \%$ & $9,6 \%$ & $12,5 \%$ & $13,4 \%$ \\
\hline & & $\%$ of Total & $4,9 \%$ & $6,1 \%$ & $2,4 \%$ & $13,4 \%$ \\
\hline & Sedang & Count & 8 & 42 & 13 & 63 \\
\hline & & Expected Count & 10,8 & 40,0 & 12,3 & 63,0 \\
\hline & & $\%$ within Disposisi & $12,7 \%$ & $66,7 \%$ & $20,6 \%$ & $100,0 \%$ \\
\hline & & $\%$ within Komunikasi & $57,1 \%$ & $80,8 \%$ & $81,3 \%$ & $76,8 \%$ \\
\hline & & $\%$ of Total & $9,8 \%$ & $51,2 \%$ & $15,9 \%$ & $76,8 \%$ \\
\hline & Rendah & Count & 2 & 5 & 1 & 8 \\
\hline & & Expected Count & 1,4 & 5,1 & 1,6 & 8,0 \\
\hline & & $\%$ within Disposisi & $25,0 \%$ & $62,5 \%$ & $12,5 \%$ & $100,0 \%$ \\
\hline & & $\%$ within Komunikasi & $14,3 \%$ & $9,6 \%$ & $6,3 \%$ & $9,8 \%$ \\
\hline & & $\%$ of Total & $2,4 \%$ & $6,1 \%$ & $1,2 \%$ & $9,8 \%$ \\
\hline Total & & Count & 14 & 52 & 16 & 82 \\
\hline & & Expected Count & 14,0 & 52,0 & 16,0 & 82,0 \\
\hline & & $\%$ within Disposisi & $17,1 \%$ & $63,4 \%$ & $19,5 \%$ & $100,0 \%$ \\
\hline & & $\%$ within Komunikasi & $100,0 \%$ & $100,0 \%$ & $100,0 \%$ & $100,0 \%$ \\
\hline & & $\%$ of Total & $17,1 \%$ & $63,4 \%$ & $19,5 \%$ & $100,0 \%$ \\
\hline
\end{tabular}


Hasil dari data Tabel 5 hasil Crosstab berdasarkan langkah proses perhitungan menggunakan bantuan Excel untuk setiap siswa ke dalam tingkat Tinggi, Sedang dan Rendah lalu dimasukan data untuk diasosiasikan dari kedua kemampuan berdasarkan tingkatan sehingga mendapatkan hasil dari Crosstab SPSS 22.

Dan berdasarkan Tabel 5 bahwa Siswa yang memiliki Rendah pada Skala Disposisi dan Rendah pada Kemampuan Komunikasi ada 1 orang. Siswa yang memiliki Rendah pada Skala Disposisi dan Sedang pada Kemampuan Komunikasi ada 5 orang. Siswa yang memiliki Rendah pada Skala Disposisi dan Tinggi pada Kemampuan Komunikasi ada 2 orang. Siswa yang memiliki Sedang pada Skala Disposisi dan Rendah pada Kemampuan Komunikasi ada 13 orang. Siswa yang memiliki Sedang pada Skala Disposisi dan Sedang pada Kemampuan Komunikasi ada 42 orang. Siswa yang memiliki Sedang pada Skala Disposisi dan Tinggi pada Kemampuan Komunikasi ada 8 orang. Siswa yang memiliki Tinggi pada Skala Disposisi dan Rendah pada Kemampuan Komunikasi ada 2 orang. Siswa yang memiliki Tinggi pada Skala Disposisi dan Sedang pada Kemampuan Komunikasi ada 5 orang. Siswa yang memiliki Tinggi pada Skala Disposisi dan Tinggi pada Kemampuan Komunikasi ada 4 orang.

Untuk kemampuan Komunikasi Tinggi ada 14 siswa diantaranya 4 siswa merespon Skala Disposisi Tinggi, 8 siswa merespon Skala Disposisi Sedang dan 2 siswa merespon Skala Disposisi Rendah karena jumlah Skala Disposisi Responnya tinggi lebih banyak dibandingkan jumlah Skala Disposisi Responnya Rendah untuk kelompok Kemampuan Komunikasi Tinggi maka respon Skala Disposisi positif. Untuk siswa Kemampuan Komunikasi Sedang ada 52 siswa diantaranya 5 siswa merespon Skala Disposisi Tinggi, 42 siswa merespon Skala Disposisi Sedang dan 5 siswa merespon Skala Disposisi Rendah, karena jumlah Skala Disposisi Responnya tinggi sama dengan jumlah Skala Disposisi Responnya Rendah untuk kelompok Kemampuan Komunikasi Sedang maka tidak ada respon Skala Disposisi untuk kelompok Kemampuan Komunikasi Sedang. Dan untuk siswa Kemampuan Komunikasi Rendah 16 orang ada 52 siswa diantaranya 2 siswa merespon Skala Disposisi Tinggi, 13 siswa merespon Skala Disposisi Sedang dan 1 siswa merespon Skala Disposisi Rendah, karena jumlah Skala Disposisi Responnya tinggi lebih banyak jumlah Skala Disposisi Responnya Rendah untuk kelompok Kemampuan Komunikasi Rendah maka ada respon Skala Disposisi Positif untuk kelompok Kemampuan Komunikasi Rendah. 


\section{Tabel 6}

Chi Kuadrat Hitung

Asosiasi untuk Skala Disposisi dan Kemampuan Komunikasi

\begin{tabular}{lrrr}
\hline & Value & df & \multicolumn{2}{r}{ Asymp. Sig. (2-sided) } \\
\hline Pearson Chi-Square & $4,316^{\text {a }}$ & 4 &, 365 \\
Likelihood Ratio & 3,845 & 4 &, 427 \\
Linear-by-Linear Association &, 165 & 1 &, 685 \\
N of Valid Cases & 82 & & \\
\hline
\end{tabular}

a. 4 cells $(44,4 \%)$ have expected count less than 5 . The minimum expected count is 1,37 .

Karena $\mathrm{P}$-Value $=0,365$ maka $P$-Value $>0,05$ artinya $H_{0}$ diterima dan $H_{1}$ ditolak dan disimpulkan bahwa tidak terdapat Asosiasi antara Skala Disposisi dan Kemampuan Komunikasi. Ini di karenakan bahwa respon dari siswa yang Kemampuan Komunikasi Rendah positif terhadap skala Disposisi yang diharapkan bahwa siswa yang Kemampuan Komunikasi Rendah negatif terhadap Skala Disposisi.

Tabel 7

Crosstab Skala Disposisi dan Kemampuan Penalaran

\begin{tabular}{|c|c|c|c|c|c|c|}
\hline & & & & Penalaran & & \\
\hline & & & Tinggi & Sedang & Rendah & Total \\
\hline Skala_Disp & Tinggi & Count & 4 & 5 & 2 & 11 \\
\hline osisi & & Expected Count & 2,5 & 5,9 & 2,5 & 11,0 \\
\hline & & $\%$ within Skala_Disposisi & $36,4 \%$ & $45,5 \%$ & $18,2 \%$ & $100,0 \%$ \\
\hline & & $\%$ within Penalaran & $21,1 \%$ & $11,4 \%$ & $10,5 \%$ & $13,4 \%$ \\
\hline & & $\%$ of Total & $4,9 \%$ & $6,1 \%$ & $2,4 \%$ & $13,4 \%$ \\
\hline & Sedang & Count & 13 & 36 & 14 & 63 \\
\hline & & Expected Count & 14,6 & 33,8 & 14,6 & 63,0 \\
\hline & & $\%$ within Skala_Disposisi & $20,6 \%$ & $57,1 \%$ & $22,2 \%$ & $100,0 \%$ \\
\hline & & $\%$ within Penalaran & $68,4 \%$ & $81,8 \%$ & $73,7 \%$ & $76,8 \%$ \\
\hline & & $\%$ of Total & $15,9 \%$ & $43,9 \%$ & $17,1 \%$ & $76,8 \%$ \\
\hline & Rendah & Count & 2 & 3 & 3 & 8 \\
\hline & & Expected Count & 1,9 & 4,3 & 1,9 & 8,0 \\
\hline & & $\%$ within Skala_Disposisi & $25,0 \%$ & $37,5 \%$ & $37,5 \%$ & $100,0 \%$ \\
\hline & & $\%$ within Penalaran & $10,5 \%$ & $6,8 \%$ & $15,8 \%$ & $9,8 \%$ \\
\hline & & $\%$ of Total & $2,4 \%$ & $3,7 \%$ & $3,7 \%$ & $9,8 \%$ \\
\hline Total & & Count & 19 & 44 & 19 & 82 \\
\hline & & Expected Count & 19,0 & 44,0 & 19,0 & 82,0 \\
\hline & & $\%$ within Skala_Disposisi & $23,2 \%$ & $53,7 \%$ & $23,2 \%$ & $100,0 \%$ \\
\hline & & $\%$ within Penalaran & $100,0 \%$ & $100,0 \%$ & $100,0 \%$ & $100,0 \%$ \\
\hline & & $\%$ of Total & $23,2 \%$ & $53,7 \%$ & $23,2 \%$ & $100,0 \%$ \\
\hline
\end{tabular}


Berdasarkan Tabel 7 bahwa Siswa yang memiliki Rendah pada Skala Disposisi dan Rendah pada Kemampuan Penalaran ada 3 orang. Siswa yang memiliki Rendah pada Skala Disposisi dan Sedang pada Kemampuan Penalaran ada 3 orang. Siswa yang memiliki Rendah pada Skala Disposisi dan Tinggi pada Kemampuan Penalaran ada 2 orang. Siswa yang memiliki Sedang pada Skala Disposisi dan Rendah pada Kemampuan Penalaran ada 14 orang. Siswa yang memiliki Sedang pada Skala Disposisi dan Sedang pada Kemampuan Penalaran ada 36 orang. Siswa yang memiliki Sedang pada Skala Disposisi dan Tinggi pada Kemampuan Penalaran ada 13 orang. Siswa yang memiliki Tinggi pada Skala Disposisi dan Rendah pada Kemampuan Penalaran ada 2 orang. Siswa yang memiliki Tinggi pada Skala Disposisi dan Sedang pada Kemampuan Penalaran ada 5 orang. Siswa yang memiliki Tinggi pada Skala Disposisi dan Tinggi pada Kemampuan Penalaran ada 4 orang.

Untuk kemampuan Penalaran Tinggi ada 19 siswa diantaranya 4 siswa merespon Skala Disposisi Tinggi, 13 siswa merespon Skala Disposisi Sedang dan 2 siswa merespon Skala Disposisi Rendah karena jumlah Skala Disposisi Responnya tinggi lebih banyak dibandingkan jumlah Skala Disposisi Responnya Rendah untuk kelompok Kemampuan Penalaran Tinggi maka respon Skala Disposisi positif. Untuk siswa Kemampuan Penalaran Sedang ada 44 siswa diantaranya 5 siswa merespon Skala Disposisi Tinggi, 36 siswa merespon Skala Disposisi Sedang dan 3 siswa merespon Skala Disposisi Rendah, karena jumlah Skala Disposisi Responnya tinggi lebih besar daripada jumlah Skala Disposisi Responnya Rendah untuk kelompok Kemampuan Penalaran Sedang maka respon Skala Disposisi positif untuk kelompok Kemampuan Penalaran Sedang. Dan untuk siswa Kemampuan Penalaran Rendah ada 19 siswa diantaranya 2 siswa merespon Skala Disposisi Tinggi, 14 siswa merespon Skala Disposisi Sedang dan 3 siswa merespon Skala Disposisi Rendah, karena jumlah Skala Disposisi Responnya tinggi lebih Kecil daripada jumlah Skala Disposisi Responnya Rendah untuk kelompok Kemampuan Penalaran Rendah maka ada respon Skala Disposisi Negatif untuk kelompok Kemampuan Komunikasi Rendah.

Tabel 8

Chi Kuadrat Hitung

Asosiasi untuk Disposisi dan Kemampuan Penalaran

\begin{tabular}{lcrr}
\hline & Value & df & \multicolumn{2}{c}{$\begin{array}{c}\text { Asymp. Sig. (2- } \\
\text { sided) }\end{array}$} \\
\hline Pearson Chi-Square & $2,534^{\mathrm{a}}$ & 4 &, 639 \\
Likelihood Ratio & 2,365 & 4 &, 669 \\
Linear-by-Linear Association & 1,016 & 1 &, 314 \\
N of Valid Cases & 82 & & \\
\hline
\end{tabular}


Karena $P$-Value $=0,365$ maka $P$-Value $>0,05$ artinya $H_{0}$ diterima dan $H_{1}$ ditolak dan disimpulkan bahwa tidak terdapat Asosiasi antara Skala Disposisi dan Kemampuan Penalaran. Ini di karenakan bahwa respon dari siswa yang Kemampuan Penalaran Rendah positif terhadap skala Disposisi yang diharapkan bahwa siswa yang Kemampuan Penalaran negatif tak ada respon terhadap Skala Disposisi. Dan untuk melihat besar ukuran dari koefisien kontingensi.

\section{Pembahasan}

Dari proses analisis diketahui bahwa pada setiap kemampuan yaitu kemampuan komunikasi dan kemampuan penalaran yang pembelajarannya dengan menggunakan Multimedia Flash CS 4.0 lebih baik dibandingkan pembelajarannya menggunakan cara konvensional, sejalan dengan Hasil penelitian menurut Latifurrohman (2013) bahwa pembelajaran menggunakan multimedia dalam bentuk animasi siswa lebih menarik dan di mengerti oleh siswa penerapan matematika saat mereka belum paham kegunaan fungsi tersebut, mereka dituntun dan dapat mandiri menyelesaikan masalah dalam soal-soal trigonometri.

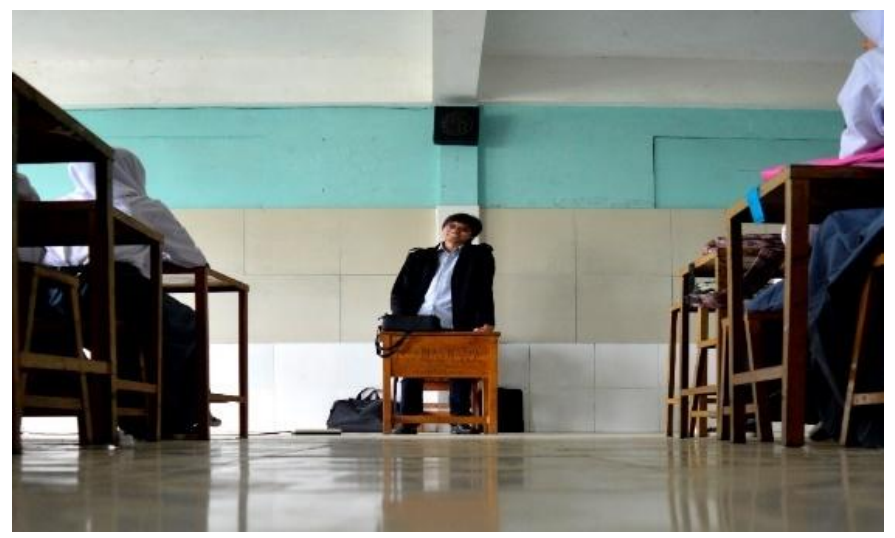

\section{Gambar 1. Memberikan Penjelasan Konsep Untuk Menerangkan Trigonometri}

Pada awalnya siswa diberikan suatu perkenalan bahwa untuk mengenal Trigonometri tidaklah jauh dari cara konsep matematika pada umumnya mereka sudah menguasainya sebelumnya. Perkenalan ini sangat penting karena siswa kelas $\mathrm{X}$ baru mengenal fungsi-fungsi Trigonometri, yang beranggapan bahwa ada fungsi yang baru matematika pasti akan mengalami kesulitan belajar matematika, di sini siswa dan guru mendiskusikan mengenai konsep dasar matematika yang sudah mereka kuasai seperti mereka mengetahui tentang segitiga siku-siku dan Teorema Phytagoras. 


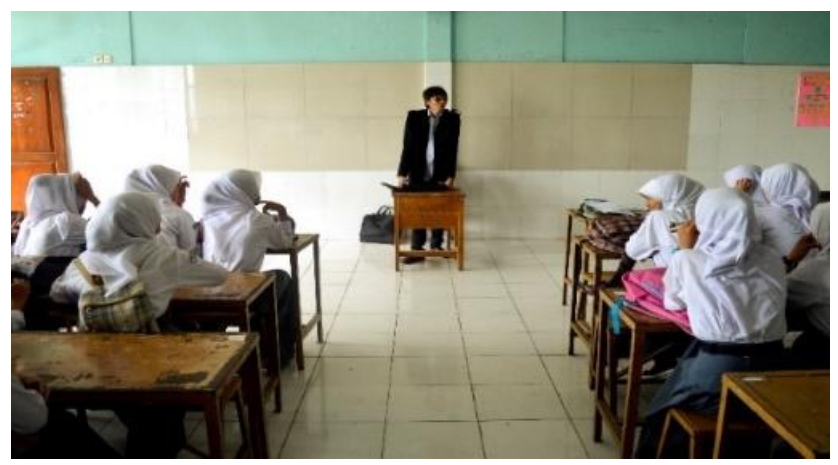

Gambar 2. Guru Berdiskusi dengan Siswa

Setelah memberikan penjelasan siswa mendapatkan gambaran bahwa fungsi trigonometri dapat dilakukan dengan konsep matematika yang sederhana, Guru akan berdiskusi kepada masing-masing siswa dari konsep-konsep dasar matematika tersebut sehingga siswa akan mendapatkan kesimpulan seperti pengertian dari macam-macam segitiga sampai siswa dapat menyimpulkan sendiri mengenai segitiga siku-siku dan juga tentang Phytagoras.

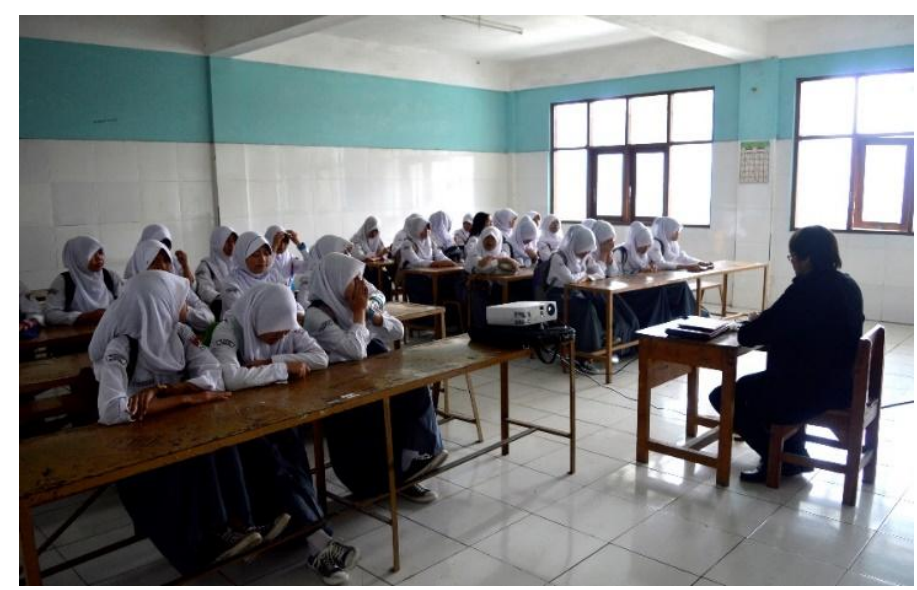

Gambar 3. Persiapan Pembelajaran Menggunakan Multimedia 


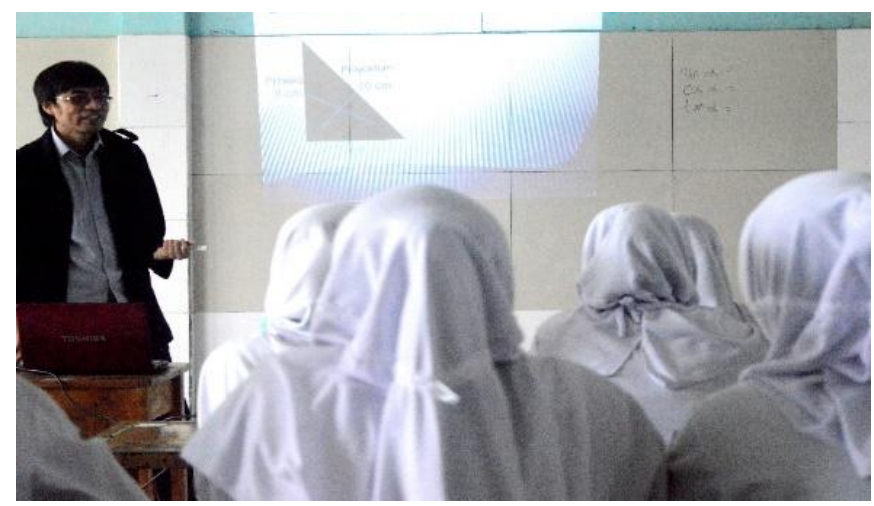

Gambar 4. Siswa Memperhatikan saat Belajar dan Mengajar

Sesuai dengan Hasil penelitian Menurut Raswaty(2010) bahwa siswa lebih tertarik belajar secara visual karena saat diberikan gambaran mereka dapat memahami memberikan kesimpulan, seperti membedakan proyeksi, proyektum dan proyektor yang nantinya akan dihubungkan dengan fungsi-fungsi trigonometri, dan mereka mendapatkan pengertian dari fungsi-fungsi tersebut.

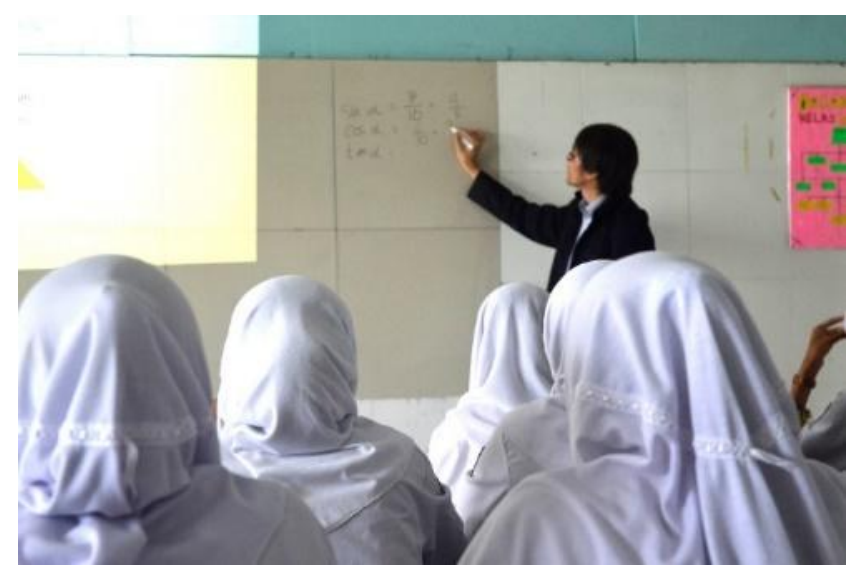

\section{Gambar 5. Guru Memberikan Contoh}

Guru memberikan contoh penerapan fungsi-fungsi trigonometri dimana siswa sudah yakin memahami fungsi-fungsi tersebut, dimana Guru selalu berinteraksi menuntun siswa sehingga mereka dapat menjawab pertanyaan dari contoh tersebut. 


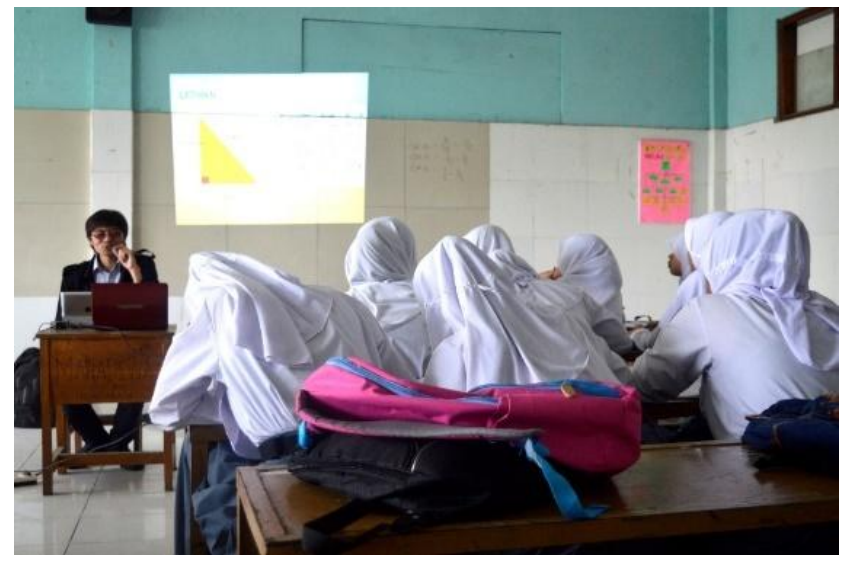

Gambar 6. Siswa Menyimpulkan dan Mencatat

Siswa diberi kesempatan untuk menyimpulkan dan mencatat setelah mereka berdiskusi mengenai contoh-contoh fungsi Trigonometri, dan juga siswa diberi kesempatan untuk bertanya jika mereka masih belum mengerti.

Siswa diberi LKS untuk latihan untuk berdiskusi antara teman dan Guru yang tujuannya agar siswa berani bertanya apa yang mereka belum paham dari materi yang sudah disampaikan dan juga mudah membuat evaluasi diri dalam menguasai materi tesebut.

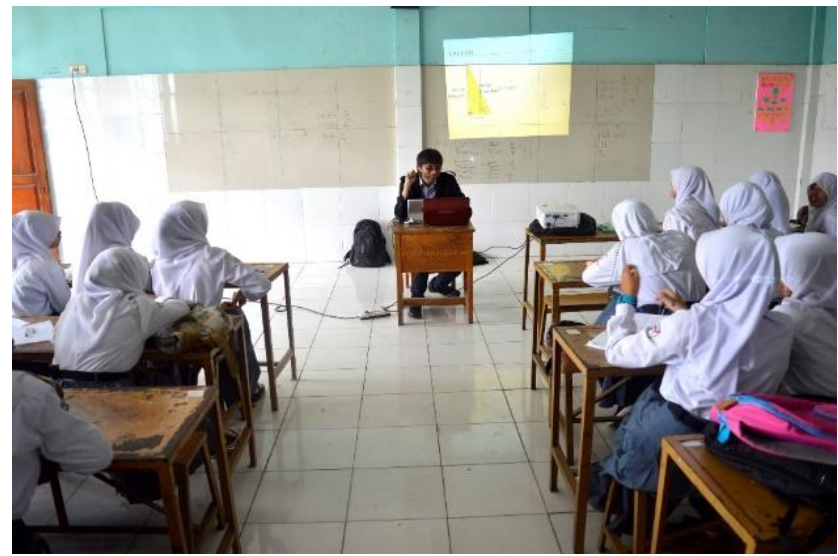

Gambar 7. Mengumpulkan Bukti dari Jawaban Siswa

Dari LKS ada latihan dimana siswa harus dapat menyelesaikan dari soal yang lebih kompleks, Guru memberikan dorongan semangat bahwa soal tersebut dapat dijawab oleh siswa, dengan memberikan gambaran konsep dasar matematika yang mereka kuasai dan bantuan multimedia agar membantu visual siswa. Dan setiap siswa 
menjawab ditulis di white board agar mudah siswa menyimpulkan dan menjawab soal tersebut.

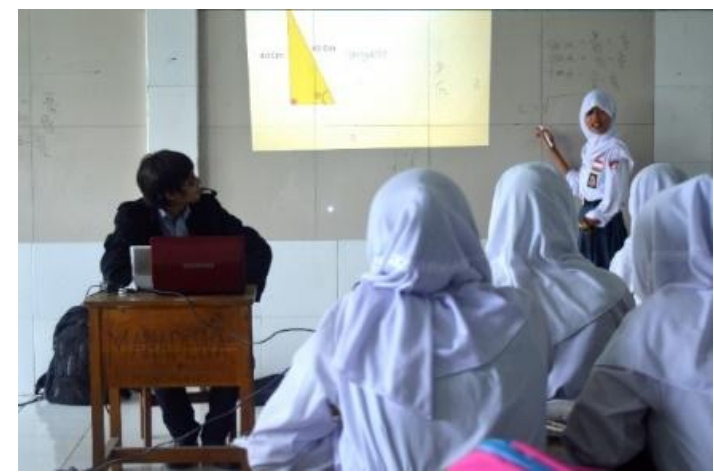

Gambar 8. Siswa diberi Kesempatan untuk Menjelaskan

Siswa diberi pertanyaan yang beragam dan setiap siswa diberikan kesempatan untuk menjawab dan menjelaskan di depan kelas. Dan ini lebih efektif bahwa mereka belajar untuk memberanikan diri membuktikan kebenaran dari kesimpulan yang sudah mereka peroleh, sehingga mereka mengerti bahwa fungsi Trigonometri dapat disolusikan dengan konsep matematika dasar yang mereka kuasai.

Dari akhir pembelajaran ini mereka mulai bersemangat untuk mempelajari fungsi trigonometri lebih luas lagi, seperti membuktikan rumus-rumus identitas trigonometri, dan muncul keiinginantahuan siswa untuk mencari cara dari berbagai sudut.

Kesulitan yang diperhadap siswa dalam pendekatan pembelajaran setelah memahami cara langkah dasar yang diberikan, siswa belum siap jika ada suatu pembuktian yang lain hanya ada beberapa siswa yang memiliki keiinginan untuk berusaha keras menemukan pembuktian berdasarkan langkah-langkah yang dipahami oleh siswa yang sesuai dengan pengertian yang sudah sepakati. Kesulitan siswa yaitu dari mana dia harus memulai karena tidak ada langkah-langkah atau rumus yang pasti, siswa terbiasa dengan rumus-rumus yang sudah jadi. Pada saat penalaran dibutuhkan banyak bukti yang dikumpulkan sehingga siswa perlu banyak dibimbing lalu dituntun mencapai suatu kesimpulan atau dengan penalaran secara induktif dan ini harus membutuhkan banyak waktu untuk mendapatkan kesepakatan bersama sehingga pada sebelum mengerjakan soal, dibutuhkan latihan-latihan sehingga siswa-siswa terbiasa membuat jawan sesuai rumusan yang sudah dibuktikan dengan cara Penalaran Deduktif. Siswa diberi kesempatan untuk menemukan jawabannya sendiri. Kesulitan yang lainnya adalah cara penyampaian siswa saat menceritakan bagaimana menjelaskan konsep soal dalam model matematika mengkaitkan ide sehingga memecahkan soal tersebut, di sini siswa dibutuhkan semangat dan dorongan bahwa dari pengetahuan dasar yang mereka 
peroleh dapat mereka kembangkan sehingga melalui jalan yang bertahap siswa juga dapat mencapai jawaban yang tepat, walaupun dipakai beberapa cara yang berbeda sesuai apa mereka pahami, dan selanjutnya memberikan penghargaan pendapat yang diajukan oleh siswa menjadi kumpulan-kumpulan model matematika sehingga pendapat siswa dapat diceritakan sesuai kebutuhan siswa untuk mendapatkan soal.

Untuk mengatasi ketidakjelasan siswa dalam pembelajaran siswa dapat diatasi dengan game animasi Adobe Flash CS 4.0 sehingga setiap siswa dapat memahami penggunaan fungsi trigonometri salah satu contoh yang mudah dimengerti adalah menghubungkan perbandingan dengan fungsi trigonometri.

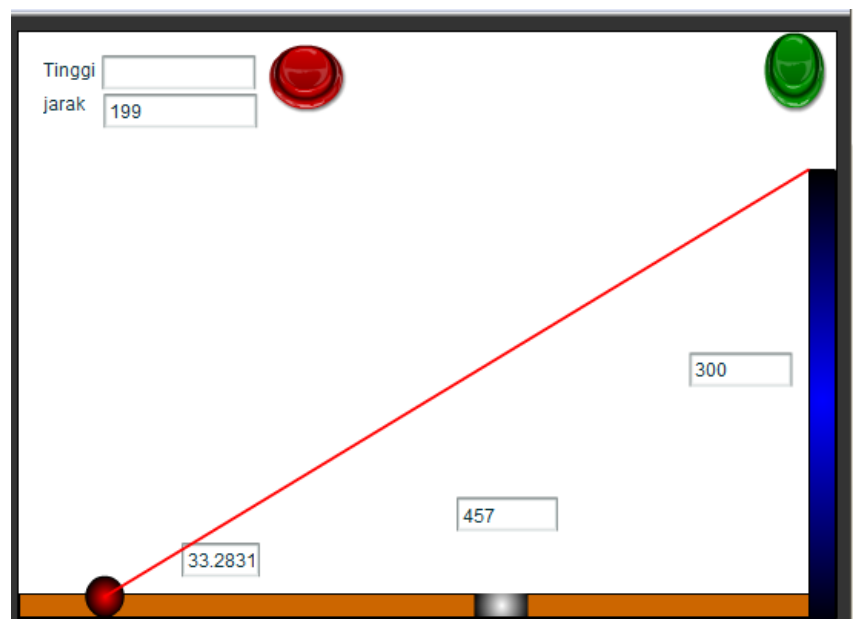

Gambar 9. Menebak tinggi batang

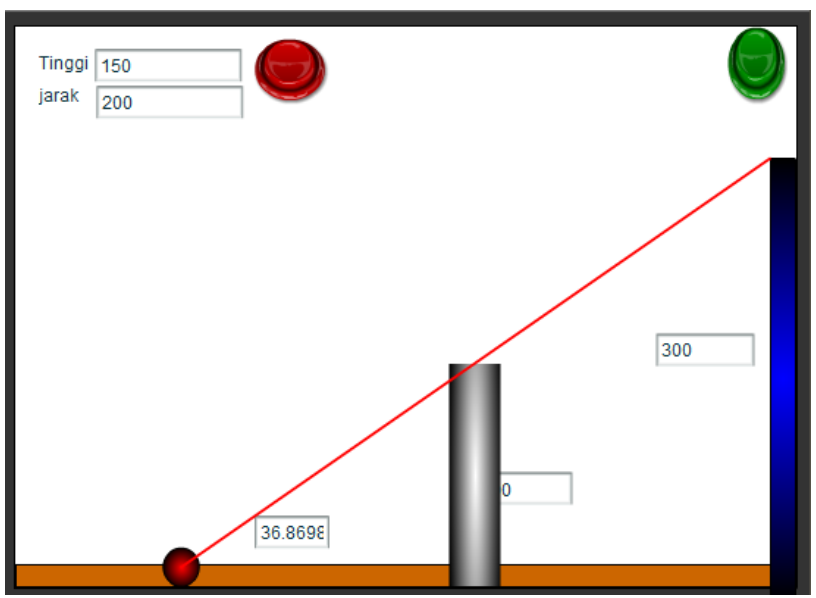

Gambar 10. Siswa Mencoba menebak tinggi batang 
Dari beberapa percobaan dari game Adobe Flash CS 4.0, siswa akan mengerti kegunaan fungsi trigonometri dari beberapa sudut kemungkinan yang dipakai, dari pemahaman tersebut siswa diberi lagi beberapa game aplikasi trigonometri sehingga proses penalaran induktif masuk ke dalam proses penalaran deduktif yang mengarahkan siswa ke dalam kesimpulan.

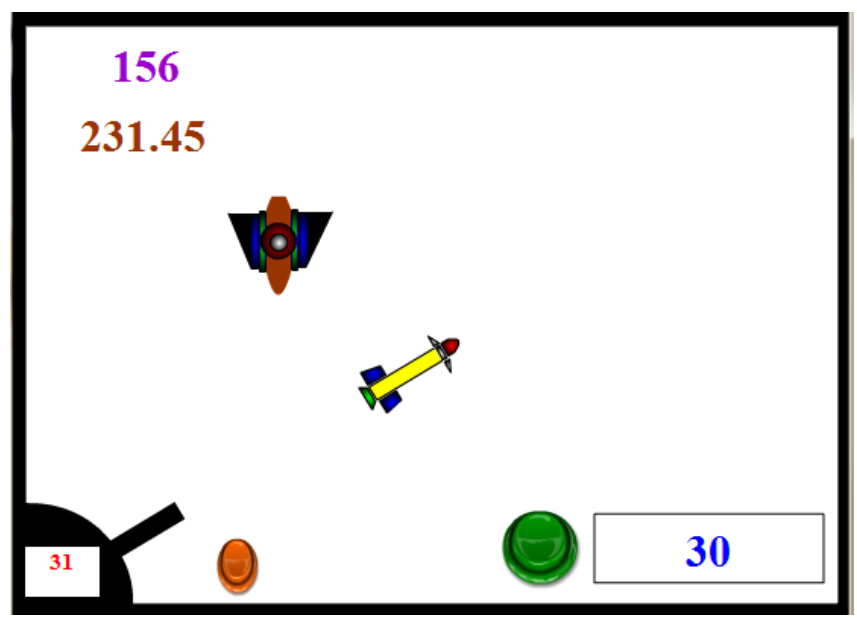

Gambar 11. Aplikasi Fungsi Trigonometri

Selain memberikan kesimpulan siswa juga menceritakan ide dari proses untuk menyelesaikan matematika dengan menggunakan game Adobe Flash CS 4.0 yang lebih variasi lagi sehingga siswa mempunyai pendapat yang akan disampaikan di depan kelas.

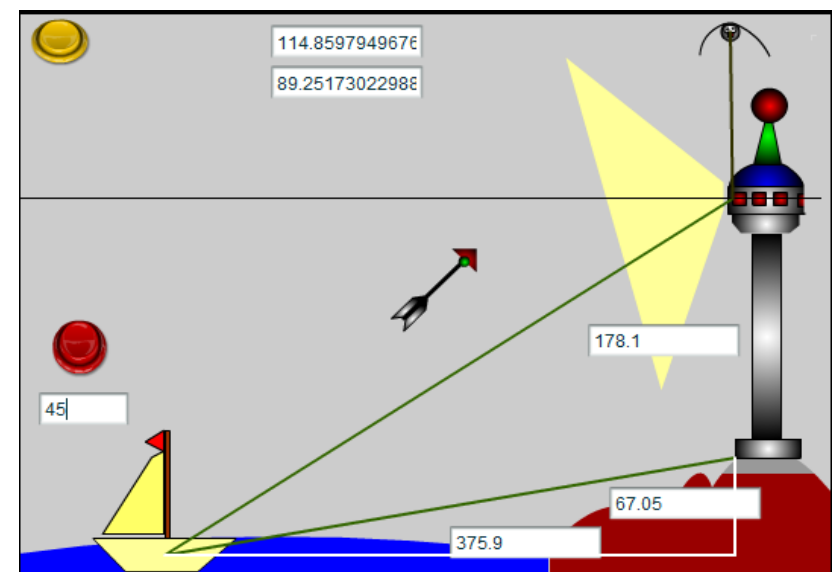

Gambar 12. Variasi Aplikasi Trigonometri 
Dengan menggunakan media Adobe Flash CS 4.0, siswa lebih aktif untuk menuangkan ide dan gagasan yang baru dari gambar animasi tersebut. Selain itu siswa juga bisa melakukan beberapa percobaan sehingga siswa paham memberikan kesimpulan. Sehingga trigonometri merupakan pembelajaran yan menyenangkan bukan lagi pelajaran yang sulit seperti mereka bayangkan.

\section{KESIMPULAN}

Berdasarkan hasil Penelitian yang diuraikan dan dianalisa sebelumnya, maka peneliti menarik kesimpulan sebagai berikut bahwa:

1. Pencapaian Kemampuan Komunikasi Matematik antara siswa yang pembelajaran dengan Pendekatan Kontekstual melalui Game Adobe Flash CS 4.0 lebih baik daripada siswa yang pembelajarannya Konvensional.

2. Pencapaian Kemampuan Penalaran Matematik antara siswa yang pembelajaran dengan Pendekatan Kontekstual melalui Game Adobe Flash CS 4.0 lebih baik dibandingkan siswa yang pembelajarannya Konvensional.

3. Peningkatan Kemampuan Komunikasi Matematik Siswa antara Siswa yang pembelajarannya dengan Pendekatan Kontekstual melalui Game Adobe Flash CS 4.0 lebih baik siswa yang pembelajarannya Konvensional.

4. Peningkatan Kemampuan Penalaran Matematik antara siswa yang pembelajarannya dengan Pendekatan Kontekstual melalui Game Adobe Flash CS 4.0 lebih baik daripada siswa yang pembelajarannya Konvensional.

5. Disposisi matematik antara siswa yang pembelajarannya melalui Game Adobe Flash CS 4.0 lebih baik daripada siswa yang pembelajarannya Konvensional.

6. Adanya Asosiasi antara Kemampuan Penalaran Matematik Siswa dengan Kemampuan Komunikasi Matematik Siswa

7. Tidak adanya Asosiasi kemampuan penalaran matematik siswa dengan disposisi

8. Tidak adanya Asosiasi kemampuan komunikasi matematik siswa dengan disposisi

\section{DAFTAR PUSTAKA}

Barrody, A, J. (1993). Problem Solving, Reasoning, and Communicating, (K-8): Helping Children Think Mathematically. New York: Merill as imprint of Macmillan Publishing Company

Elida, N (2012), Meningkatkan Kemampuan Komunikasi Matematik Siswa Sekolah Menengah Pertama Melalui Pembelajaran Think-Talk-Write (TTW). Jurnal Infinity. Vol.1 No.2 (178-187).

Hidayatullah, P., Daswanto, A., Nugroho .S.P. (2011) Membuat Mobile Game Edukatif Dengan Flash. Bandung: Penerbit INFORMATIKA. 
Hulu, P. (2009). Meningkatkan Kemampuan Penalaran Matematik siswa Sekolah Menengah Pertama Menggunakan Pendekatan Pembelajaran Berbasis Masalah. Tesis pada SPS UPI Bandung: Tidak Diterbitkan

Hutapea, N.M. (2013). Peningkatan Kemampuan Penalaran, Komunikasi Matematis dan Kemandirian Belajar Siswa SMA melalui Pembelajaran Generatif. Disertasi pada SPS UPI Bandung: Tidak Diterbitkan.

Irianto, B. (2007). Menumbuhkembangkan Kemampuan Pemahaman dan Komunikasi Matemayik Siswa SMP Melalui Think-Talk-Write. Tersedia Pada: http//yourfavorite.com. Diakses pada 15 April 2012.

Jupri (2004). Pengembangan Desain Pembelajaran Matematika Realistik Untuk Menumbuhkembangkan Kemampuan Pemecahan Masalah dan Komunikasi Mtematik Siswa. Bandung: Tidak diterbitkan

Keraf, G. (1982). Arguned dan Narasi. Komposisi Lanjutan III. Jakarta: Gramedia.

Kristianto, W. H. (2007). Penggunaan Media Pembelajaran Animasi Simulasi Komputer Terhadap Pemahaman Konsep Gerak ditinjau dari Penalaran Abstrak. Surakarta.: Program Pascasarjana Pendidikan Sains.

Latifurrohman, M. (2013). Pengembangan Media Pembelajaran Matematika Menggunakan Adobe Flash CS 4.0 berbasis Kontruktivisme Untuk Meningkatkan Hasil BelajarSiswa SMA. Semarang: IKIP PGRI Semarang.

NCTM. (1989). Curriculum and EvalutionStandards for School Mathematics. Reston, Virginia: NCTM.INC.

NCTM [National Council of Teacher of Mathematics](1991). Principles and Standrads for School Mathematucs. Reston Verginia: NCTM.INC

Soedjadi, R. (2000). Kiat Pendidikan Matematika di Indonesia Konstruksi Keadaan Masa Kini Menuju Harapan Masa Depan. Jakarta: Dirjend Dikti Depdiknas.

Sugiyanto. 2009. Model-Model Pembelajaran Inovatif. Surakarta: UNS Press.

Sumarmo, U. (2012). Bahan Belajar Matakuliah Proses Berfikir Matematik. Bandung: Tidak diterbitkan.

Sumarmo, U. (2003) Pembelajaran Keterampilan Membaca Matematika pada Siswa Sekolah menengah. Makalah pada Seminar Nasional Pendidikan FMIPA UPI. Bandung: Tidak Diterbitkan

Wardani, S. (2002). Pembelajaran Pemecahan Masalah Matematik Model Kooperatif Tipe Jigsaw. Diakses pada tanggal 27 Mei 2011 pada http://www.educative.mx/adliva.pdf. 